\title{
Kućni trošak pelješke obitelji Braenović s kraja 19. stoljeća: izvor za iščitavanje svakodnevice
}

\author{
JASENKA MASLEK \\ Sveučilište u Dubrovniku
}

\begin{abstract}
U radu se na temelju analize prihoda i rashoda pelješke obitelji Braenović, ustanovljenih na osnovi njihove vlastite evidencije, osim financijskog stanja istražuje i status te obitelji, odnosno njihova svakodnevica s kraja 19. stoljeća. Nakon uvodnog prikaza društvenih okolnosti u kojima je obitelj egzistirala, promatra se svakodnevni život i rad obitelji od 1894. do 1897. godine i tako se iščitava dio obiteljske povijesti u ekonomskom, ali i intimnom smislu. Prikazuju se navike pojedinih članova obitelji, način njihova odijevanja te se doznaje visina nadnica običnog težaka, polovnika, i njegova kupovna moć s obzirom na cijene navedene u kućnom trošku. Zahvaljujući bilješkama o obiteljskoj trgovini vinom te prikazanim prihodima od berbe i prodaje vina, može se precizno odrediti i financijsko stanje obitelji. Bilježenje sličnih podataka u doba druge ili "velike konjunkture" vina omogućuje isticanje posebnosti vinogradarske zbilje na Pelješcu krajem 19. stoljeća u odnosu na stanje te gospodarske grane u Dalmaciji.

Ključne riječi: zemljovlasništvo, obiteljska svakodnevica, kućni trošak, financijski učinak berbe, vinske konjunkture
\end{abstract}

S namjerom da se osvijetli njihov život na Pelješcu s kraja 19. stoljeća, u radu se analizira popis prihoda i rashoda zemljovlasničke obitelji Braenović iz Grude kraj Potomja, a na osnovi obiteljske evidencije koja je poslužila kao izvor za istraživanje. ${ }^{1}$ Najprije će se izložiti povijesni i društveni okvir te gospodarske prilike u kojima je obitelj živjela, a zatim pojasniti kako je funkcionirala u danim okolnostima. Posebna je pažnja posvećena strukturi obitelji organiziranoj kao kućna zadruga. Analiza se proteže od vremena kad

\footnotetext{
${ }^{1}$ Obrađeni izvor je u stvari bilježnica koja je pronađena na tavanu obiteljske kuće u Grudi na Pelješcu. Bilješke su vođene od 1871. godine na nerazgovijetnom talijanskom jeziku, ali s obiljem dragocjenih podataka o kretanju cijena vina i vinskih prerađevina. Godine 1894. se pod nazivom "kućna troška" pojavljuje iscrpan popis kupljenih namirnica i potrepština na hrvatskom jeziku. Posebno su bilježeni godišnji prihodi, zarada od prodana vina i ostalih vinskih proizvoda, tako da se mogao dobiti detaljan izračun obiteljskih prihoda.
} 
su obitelj činila samo trojica braće, dok je 1912. godine ta proširena obitelj ${ }^{2}$ brojala 14 članova sa zajedničkom blagajnom. S obzirom na financijsku neodijeljenost, proširenom možemo nazvati i zajednicu trojice braće iz 1893. godine, kao i 14-eročlanu obiteljsku zajednicu iz 1912. godine. ${ }^{3}$ Navedeni izvor omogućava praćenje života i rada obitelji u lokalnoj zajednici u doba kad je zbog pogoršanih gospodarskih uvjeta raspadanje proširenih obiteljskih zajednica u drugim dijelovima Hrvatske i bližeg okružja u punom zamahu. Ovdje to nije tako. Dapače, analiza kućnoga troška i obiteljskih prihoda rasvijetlit će društveni i gospodarski kontekst povijesnog razdoblja u kome je privređivanje jedne obitelji na Pelješcu potkraje 19. stoljeća bitno olakšano upravo zajedničkim gospodarenjem i upravljanjem obiteljskom imovinom. Zajedništvo u proširenoj obitelji učvrstilo je njezin položaj unatoč krizi u gospodarstvu. Unatoč izraženim nepovoljnim tendencijama, zemljišni posjed nije dijeljenjem rascjepkan niti je kapital obezvrijeđen. Uz nužne prilagodbe i zadržavanjem zajedničkog načina života egzistencija te obitelji je olakšana, što pokazuje i analiza kućnog troška. Zajedničko gospodarenje te financijsko i imovinsko zajedništvo pretpostavke su uspješnosti te obiteljske zajednice. ${ }^{4}$ Upravo od te premise polazi ovaj rad.

Namjera je pomoću opisanog izvora "odozdo" predočiti djelić povijesti mentaliteta, tadašnjega pogleda na svijet te rekonstrukcijom života obitelji prikazati različite aspekte svakodnevice malog čovjeka uvjetovane gospodarskim kretanjima i demografskim ciklusima kao dijelovima kvantitativne i serijalne povijesti kako ih je zamislio sljedbenik škole Annales, Ernest Labrousse. Obiteljski je kućni trošak gotovo idealan izvor za Labrousseovu tezu da bi gospodarsku povijest trebalo proučavati u nizovima ili serijama (Bertoša 2002: 332). Iz njega se iščitavaju cijene pojedinih namirnica, visina nadnica, u njemu se odražavaju gospodarski ciklusi i iskazuju konjunkturna razdoblja vinogradarstva, a svi zajedno pridonose produbljenju pogleda na različita

${ }^{2}$ Ovom sintagmom zamjenjuje se ranije uvriježeni izraz zadruga, koji je u etnološkoj uporabi opterećen i drugim značenjima i poistovjećuje se sa zajednicom više bračnih parova - nuklearnih obitelji - dok je njezino distinktivno obilježje zajedničko vlasništvo. Zato Jasna Čapo Žmegač u etnološkom kontekstu kod srodnika preferira razlikovanje samo nuklearne i proširene obitelji (Čapo Žmegač 1998: 253). Ista se autorica u ranijim radovima koristi sintagmama "jednostavna” ili "složena kućanstva”, pri čemu složenim smatra kućanstva s dva ili više bračnih parova ili obitelji (Čapo 1991: 333-334). Sintagma kućna zadruga kao oblik obiteljske zajednice i dalje se učestalo rabi u povijesnoj literaturi (Černelić 2009: 302). 0 navedenu pojmu i njegovu značenju vidi i Pavličević (2010: 52).

${ }^{3}$ Prema Baltazaru Bogišiću osnovnu razliku među obiteljima čini vlasnička struktura i način nasljeđivanja, odnosno tip vlasništva i kako se tim vlasništvom upravlja. Bogišić smatra da "nuklearne i proširene obitelji nisu dva tipa/oblika obitelji, nego isti tip obitelji u različitim trenucima njezina postojanja" (Bogišić prema Čapo Žmegač 1998: 256). O modelima obitelji u Europi i povijesti obitelji u Hrvatskoj vidi i Čapo Žmegač (1996: 179-196).

${ }^{4}$ Ekonomska emigracija uvjetovana gospodarskom krizom bila je i u Lici važan čimbenik u raspadanju obiteljskih zadruga u drugoj polovici 19. stoljeća, ali su istodobno prilagodba promijenjenim robnonovčanim uvjetima i stvaranje specifičnih oblika gospodarenja omogućili opstojnost nekih nepodijeljenih obiteljskih zajednica sve do druge polovice 20. stoljeća (Černelić 2009: 307). 
područja djelovanja onodobnog čovjeka kojim je zaokupljena povijesna antropologija (Gross 1996: 84). Takvom čovjeku tradicionalističkih shvaćanja i s bremenom naslijeđenih vrijednosti već zaboravljene dubrovačke gordosti dodana je dimenzija vremena koje zorno dočarava Braudelovu povijest "dugoga trajanja", gotovo nepokretnu povijest o čovjeku i njegovim odnosima s okružjem. Prema Braudelu je takav čovjek uronjen u "jednu polaganu povijest koja teče, koja se transformira, sastavljenu od upornih povrataka, ciklusa koji se bez prestanka ponavljaju" (Braudel 2001: 16).

Kućni trošak kao izvor nudi razne mogućnosti proučavanja i rekonstruiranja vremena i prostora djelovanja obitelji, tako da, na primjer, na osnovi pretplate na određene časopise i članstva u udrugama možemo zaključivati o političkim uvjerenjima i opredjeljenjima članova obitelji. Ipak, ovdje će se, polazeći od učestalosti i vrste kupljenih namirnica i ostalih rashoda upisanih u troškovnik, prikazati navike, način odijevanja, strukturu izdataka članova obitelji, uz poseban osvrt na ekonomske učinke proizvodnje i prodaje vina, i u ovoj obitelji i na središnjem najvinorodnijem dijelu Pelješca u doba druge ili "velike konjunkture" vina. ${ }^{5}$ Procjenom obiteljskog financijskog stanja pokušat će se sagledati utjecaj nadolazeće gospodarske krize koja je potkraj 19. stoljeća svom silinom pogodila upravo dalmatinsko vinogradarstvo i vinarstvo, a naročito teške posljedice ostavila na demografskom planu.

\section{DRUŠTVENE I GOSPODARSKE OKOLNOSTI NA PELJEŠCU U 19. STOLJEĆU}

Za vrijeme Dubrovačke Republike kmetski je proizvodni odnos u poljoprivredi, koji je prevladavao u Konavlima, Primorju i na Pelješcu, bio uređen odredbama Republike i običajnim pravom. Posebnost dubrovačkog kmetstva proizlazi iz osobitosti aristokratskoga dubrovačkog sloja koji je imao istodobno obilježja feudalaca i trgovačke buržoazije - posjedovao je gotovo svu zemlju i imao političku vlast, ali je bio i nositelj gospodarskoga života u gradu (Glavina 2010: 89, 92). Problemi zemljišnih odnosa naročito postaju aktualnima naglim siromašenjem vlastele i gospodarskim nazadovanjem nakon propasti Dubrovačke Republike, kojoj je Pelješac pripadao više stoljeća. Propast Republike nije donijela bitnije promjene u agrarnim odnosima, nije poboljšala položaj seljaka niti je značila ukidanje kmetskih odnosa. Za njiho-

${ }^{5}$ To je razdoblje najvećega izvoza dalmatinskih vina tijekom 19. stoljeća koje je trajalo od oko 1867. do 1892. godine, a uvjetovano je propašću francuskih vinograda, koje je poharala filoksera. Obično se dijeli na tri faze. U prvoj je zamjetno lagano oživljavanje vinogradarstva koje traje do oko 1875. godine, konjunktura kulminira od oko 1876. do oko 1885. godine, a zatim se poletno razdoblje u trećoj fazi polako gasi i završava gubitkom francuskoga tržišta nakon višestrukog povećanja uvozne tarife za dalmatinsko vino koju je Francuska uvela 1892. godine (Kraljević 1994: 88-112). 
vo razrješenje ovdašnji seljak će se bezuspješno boriti cijelo 19. stoljeće, sada pod austrijskom vladavinom, koja 1848. godine i službeno ukida kmetstvo, ali ne i na ovom području (Ćosić 1999: 257). Istodobno dolazi do ponovnog procvata pelješkog pomorstva. Uzme li se u obzir da je u povećanom izvozu vina sredinom stoljeća najveći profit pripadao brodarstvu te da je na tim brodovima plovilo dosta pomoraca i iz brdskih vinorodnih naselja Pelješke župe kojoj je pripadalo i naselje Gruda, logično je pretpostaviti da je upravo taj kapital najveća korist koju Pelješcu donosi razdoblje prve konjunkture vina. ${ }^{6} \mathrm{Na}$ spomenutom središnjem dijelu Pelješca bilo je dosta pomorskih kapetana i drugih pomoraca koji su financijski pomagali svoje obitelji, tako da su se oni imućniji otkupljivali od kmetstva i kupovali zemlju propalih vlastelina. Tako nestaje i obveza službe "na gosparevu" i davanja poklona, ali ostaje davanje prihoda sa zemlje jer su novi vlasnici zemlje postali "novi gospari", dajući zemlju na obradu siromašnijim obiteljima uz obvezu davanja trećine, a kasnije četvrtine prihoda sa zemlje.

S druge strane, posljedica značajnog porasta otkupljivanja od kmetstva i povećanja broja zemljovlasnika je usitnjavanje imanja, dok trgovanje zemljom potiče lihvarsku aktivnost. Inače, kraj 19. stoljeća je i u Hrvatskoj doba intenzivnijeg raspada većih kućnih zajednica, što dodatno pridonosi usitnjavanju posjeda koji, uz istodobno naraslo stanovništvo, više nije dovoljan za prehranjivanje tolikoga broja ljudi. Povećanje broja inokosnih obitelji i diobe zahtijevale su veća sredstva za izgradnju odijeljenih kuća za stanovanje, gospodarskih zgrada i nabavku alata i oruđa za obradu zemlje, što je prije bilo zajedničko obiteljsko vlasništvo, a posljedica je veće siromaštvo i dodatno zaostajanje u modernizaciji obrade i poljoprivrednoj proizvodnji (Stipetić 1959: 108-110). Odvija se, dakle, proces suprotan općim modernizacijskim tendencijama u drugoj polovici 19. stoljeća: umjesto okrupnjavanja zemljišta koje je preduvjet povećanju prinosa i uporabi mehanizacije pri obradi zemlje, ovdje male i raštrkane parcele traže ulaganje više rada za niske prinose koji neće biti dovoljni ni da prehrane obitelj niti će omogućiti dalje ulaganje u zemlju. I u Dalmaciji je ono malo ranije skupljena kapitala utrošeno na sve češće diobe umjesto da je unaprijedilo vinogradarstvo koje nemilice počinje napadati peronospora, a zatim i filoksera (Vekarić, N. 1992a: 97-102).

\footnotetext{
${ }^{6}$ Naziva se i malom konjunkturom i predstavlja vrijeme vinogradarskoga poleta od oko 1850. do oko 1857. godine praćeno naglim povećanjem vinogradarskih površina u Dalmaciji (Kraljević 1994: 24).

${ }^{7}$ Ove su obveze proizlazile iz seljakove izjave o podčinjenosti kojom se seljak obvezuje da će gospodaru služiti i činiti sve ono što su dužni činiti seljaci druge vlastele, prema običaju Stona i Pelješca ili prema običaju drugih težaka Pelješca, nazivajući se gospodarovim čovjekom, težakom ili radnikom. Običaj je nalagao odrađivanje tlake ili radnu rentu kao naknadu za korištenje kuće, tzv. službu, koja se obavljala na gospodarevoj carini (alodiju), a za uživanje vrta i pravo na ispašu i sječu drva kmet je bio dužan davati poklone, kao što su svinjski but ili glava, pogača, jaja, kokoši, janjad, koje je donosio gospodaru o pokladama, za Božić ili Uskrs (Šundrica 1980: 124-126).
} 
Pomorstvo, kao najveći izvor kapitala ovoga područja, već nakon 1875. godine osjeća teret konkurencije parobroda, a otežano poslovanje rezultiralo je 1880-ih likvidacijom dvaju najvećih dalmatinskih pomorskih društava, Pelješkoga pomorskoga društva u Orebiću i Dubrovačkoga pomorskog društva. Propadanjem jedrenjaka propala su i brodogradilišta, pomorci i radnici u brodogradnji ostali su bez posla, a parobrodarstvo je, uz preuzimanje duge i velike obalne plovidbe, uzrokovalo i propadanje male obalne plovidbe. I ovdje je, naime, preusmjeravanje trgovačkog prometa na parobrodarski prijevoz sve više uzimalo maha. Nisu se ostvarila ni predviđanja da će otvaranje Sueskoga kanala 1869. godine oživjeti dalmatinske luke pa je opadanjem gospodarske aktivnosti pao i standard, što je mnogima onemogućilo egzistenciju i uvjetovalo masovno emigriranje (Vekarić, S. i N. Vekarić 1987: 65).

Istodobno, u pelješkim poljoprivrednim područjima upravo je u to doba najočitiji nagli porast stanovništva zbog smanjenja smrtnosti uz još relativno visoke stope nataliteta, pa ograničenost obradivih površina, izoliranost i izostanak modernizacijskih procesa uvjetuju nagli porast iseljavanja. Općenito je ova faza demografske tranzicije ${ }^{8} u$ ruralnim sredinama prouzročila dublje socijalne probleme jer su izravno uvjetovani društveno-ekonomskim napretkom, a na Pelješcu, kao i u Hrvatskoj, taj je proces prethodio modernizaciji umjesto da teče paralelno s njom, pa je i pojava deformativnih i specifičnih procesa bila češća (Vekarić, N. i B. Vranješ-Šoljan 2009: 59). Oni se očituju u naglom porastu stanovništva, arhaičnosti zemljišnih odnosa, usitnjavanju posjeda i siromašenju, pa je iseljavanje bio jedini mogući način razrješenja krize i ponovne uspostave ravnoteže. ${ }^{9}$

\section{O OBITELJI}

Braenovići su bili zemljoposjednička obitelj i bavili su se vinogradarstvom. Dio zemlje imali su u zakupu, a kao kmetovi Braenovića u obiteljskoj predaji spominju se obitelji Grlan, Škrabalo, Trojanović, Tomelić, koji su davali prinose u grožđu, vinu, povrću i pšenici. Prezime Braenović se na Pelješcu bilježi u 16. stoljeću, u mjestu Gornje Pijavičino, odakle je izvjesni Mato Ivanov Braenović (1784-1853.) preselio 1814. u Grudu, kao domazet kuće Carević (Vekarić, N. 1995: 105). Njegov sin Ivan ima tri kćeri i tri sina i sredinom 19. stoljeća dograđuje kuću. Kuća je bila na kat, građena od kamena, ali vezivni materijal nije bilo vapno, nego tzv. krvavac, crvena zemlja pomiješana s pijeskom, što

\footnotetext{
${ }^{8}$ Ta pojava označava razdoblje prijelaza s tradicionalnog, primitivnog režima reprodukcije stanovništva s visokim stopama nataliteta i mortaliteta na moderni režim niskih stopa prirodnog kretanja stanovništva. To je proces etapnog razvoja uvjetovan ukupnošću društveno-gospodarskog i kulturnog razvoja (Wertheimer-Baletić 1999: 105-111).

${ }^{9} \mathrm{O}$ tome opširnije u Nenad Vekarić (1992a: 97-102).
} 
se vidjelo u kasnijim rekonstrukcijama zgrade. Izgled gospodarskih zgrada, čak i staja koje su bile građene u kamenu i nalazile se na uzvisini iznad kuće za stanovanje, upućuje na dobro imovno stanje domaćina.

Nakon udaje sestara i smrti roditelja 1889. i 1890. godine u obitelji ostaju tri brata: Mato, Jozo i Ivo, od kojih se ženi najprije Mato 1893. godine, zatim Jozo 1894. godine, dok se Ivo oženio godine 1906. Mato i žena Agneza nisu imali potomaka, a Jozu i ženi Frani se prvi sin Ivan rodio 1897. godine pa je u promatranom razdoblju od 1894. do 1897. godine u toj proširenoj obitelji živjelo pet, odnosno šest članova. ${ }^{10}$

Iako je proces raspadanja složenih kućanstava u to doba bio u punom zamahu, može se reći da su Braenovići živjeli u tom patrijarhalnom sustavu više obitelji i naraštaja, u ravnopravnoj zajednici života, rada, autarhične proizvodnje i potrošnje na zajedničkom imanju koje vodi starješina (Pavličević 1989: 23). ${ }^{11}$ Iz podataka o kućnom trošku dâ se zaključiti da je starješina bio Jozo, a bilješke o trošku vodio je Mato. Postavlja se, međutim, pitanje zašto su trojica braće i nakon ženidbe ostala živjeti zajedno i nisu podijelili zemlju koje su imali dovoljno. 0 tome izvor ne pruža nikakve podatke, ali se može s velikom sigurnošću pretpostaviti da je na Pelješcu i potkraj 19. stoljeća prevladavao ukorijenjeni sustav običaja iz doba Dubrovačke Republike, po kojemu je cilj ukupnog djelovanja svakoga člana obitelji bio osigurati prosperitet i napredovanje. Kako je obradive zemlje u Republici bilo malo, običaj je nalagao da imanje nasljeđuje najstariji sin dok su se ostali morali snalaziti odlaskom u emigraciju, svećenstvo, plovidbu ili su postajali domazeti. Ako su ostali u kući, nisu se smjeli ženiti. Cilj je bio spriječiti diobu zemlje pod svaku cijenu, pa nije bio rijedak ni primjer levirata - običaja da se s udovicom ženi brat umrloga (Vekarić 1992b: 26-27). Cjelovitost imanja mogla se osigurati i oporučno pa je vrlo vjerojatno otac svojom posljednjom voljom obvezao braću Braenović na zajednički život. ${ }^{12}$ U 19. su stoljeću i u drugim europskim zemljama vladale različite prakse u nasljeđivanju. Ali razlike nisu proizla-

\footnotetext{
${ }^{10}$ Iskorišteni su podaci iz obiteljskog arhiva te matične knjige rođenih, vjenčanih i umrlih župe Kuna Pelješka.

${ }^{11}$ Raspravljajući o postojanju i konceptu kućnih ekonomskih zajednica Emile Sicard naglašava da se one ne smiju promatrati kao tip obiteljske zajednice, nego zajednice autoriteta s naglaskom na zajedništvu - vlasništvo je zajedničko i nedjeljivo, zajednički je i rad, a takav je i autoritet (Sicard 1974: 31).

12 Slični se primjeri mogu naći i u oporukama kapetanskih i brodovlasničkih obitelji u Orebiću. Primjerice, Mato Cvita Fisković u oporuci sastavljenoj 1789. godine ostavlja kuću sinu Cvitu, dok drugoj dvojici sinova jamči pravo na uživanje kuće, ali uz uvjet da ostanu živjeti zajedno u spomenutoj kući. Ako se odvoje, gube pravo na dio kuće. (Državni arhiv u Dubrovniku, Testamenta Notariae, ser. 10, sv. 85, f. 162-164) Na europskom prostoru su čak i na istom području zamjetne razlike u obiteljskom organiziranju, ovisno o promatranom razdoblju ili pripadnosti određenom društvenom sloju. Tako se na primjer veliki broj nadničara među zemljoradničkim stanovništvom na Iberijskom poluotoku i u južnoj Italiji smatrao uzrokom prevladavanja nuklearnih obitelji, dok su seljaci koji su imali imanje živjeli češće u složenim obiteljima (Sarti 2006: 51).
} 
zile samo iz lokalnih tradicija nego iz ukupnosti društveno-ekonomskih, demografskih i gospodarskih prilika povezanih s osnovnom djelatnošću i visinom obiteljskih prihoda. U Provansi su, na primjer, svi sinovi nasljeđivali jednako, dok se ženama osiguravao miraz, a kako se zemlja ne bi usitnila, brojna oženjena braća živjela su zajedno, na nepodijeljenoj imovini. Tako je nastao frérèches, odnosno obitelji sastavljene od oženjene braće koja zajedno žive potvrđujući da sustav ravnopravnog nasljeđivanja ne dovodi nužno do dijeljenja imanja i osnivanja nuklearnih obitelji (Sarti 2006: 64). Obitelj Braenović dokaz je da je takva obiteljska struktura postojala i na Pelješcu.

Treba istaknuti i starosnu dob braće prilikom stupanja u brak. Mato je imao 35 godina, Jozo 29, a Ivo 34 godine, što potvrđuje pravilo da u neodijeljenim kućama na ovom području muškarci nisu bili prisiljeni na ranu ženidbu kako bi osigurali dodatnu radnu snagu, nego su preuzimali ulogu preminulih roditelja.

Broj članova te zajednice kasnije će se povećati jer se Jozi nakon sina Ive 1897. godine redom rađaju sinovi: Antun (1899.), Josip (1902.), Mato (1904.) i Tomislav (1906.), kada se ženi i treći brat Ivo i dovodi u zajednicu ženu Franu. Dakle, 1906. bilo je 11 neodijeljenih članova, a 1912. godine sa Ivinim sinovima 14 članova. Braća Ivo i Jozo Braenović konačno su podijelili imanje 1916. godine nakon smrti brata Mate.

\section{OBITELJSKA SVAKODNEVICA}

Za sve radove na zemlji koja nije bila dana na obradu kmetovima Braenovići su plaćali nadnice od 50 solada. Nekad su plaćali i po 15 do 20 nadnica odjednom, pa je to bio važan mjesečni izdatak u doba intenzivnijih radova u vinogradu. Ali, ako su kupili npr. sjeme graška, sljedeći bi dan platili nadnicu za njegovo sijanje. A kolika je bila vrijednost nadnice pokazuje podatak da je cijena kilograma šećera iznosila 31,5 solada, što znači da je nadničar za svoj cjelodnevni rad mogao kupiti malo više od jednog i pol kilograma šećera.

Kao pravo seosko domaćinstvo držali su stoku - ovce, koze, svinje i tovarne životinje: dvije mazge i magarce. Dvije svinje su se kupovale u svibnju i hranile do Božića, a mazge i magarci su bili neophodni za rad u polju, pregon vina ili prenošenje većeg tereta. Bez obzira na to meso i riba su se redovito kupovali. Najviše je izdataka bilo tijekom rujna u doba berbe grožđa jer je tada bila potrebna dodatna radna snaga. Tako je 3. rujna 1896. godine kupljeno mesa za četiri forinte i 56 solada, a potkraj istoga mjeseca za četiri forinte i 68 solada. Od ostalih prehrambenih artikala kupovali su tjesteninu, rižu, kavu, šećer, kekse, sir, limune, naranče, začine, a na veliko brašno, sol te 
hranu za životinje. ${ }^{13}$ Na veliko se kupovao i sumpor neophodan za posipanje vinograda radi zaštite od bolesti vinove loze.

Posebno je zanimljiva stavka u troškovniku koja pokazuje kupnju većih količina sapuna, do 60 kilograma, i pet do osam kilograma bušinca ili buha$\check{c} a{ }^{14}$ To se kupovalo obično u lipnju ili početkom srpnja, a služilo je za poseban pripravak za zaštitu grožđa od nametnika, neke vrste crva. U određenoj količini vode otapao se prah buhača, zagrijavao i tomu se dodavao sapun koji se rastapao. Tako pripremljena smjesa se u mezarolama ${ }^{15}$ prenosila u vinograd, gdje bi se svaki grozd umakao u smjesu držeći posudu odozdo, ispod tek ovješenih mladih grozdova. Bio je to vrlo zahtjevan i spor posao, a takva vrsta zaštite plodova bilježi se i u prvim desetljećima 20. stoljeća. ${ }^{16}$

Vrlo su raznolike vrste materijala od kojih se šivala odjeća. Budući da posebna narodna nošnja središnjeg dijela Pelješca nije poznata, po količinama kupljenoga materijala može se pretpostaviti da su žene nosile duge suknje i podsuknje, tzv. pandila, te obveznu maramu na glavi. Kupovao se kambrik, saten, velur, svila, ali i obično platno za radnu odjeću ili posteljinu (stampa, tela rusa, botana). Iako muškarci nisu fizički radili u polju, kupovali su platno vrste oćeta za šivanje radnih košulja, grubo platno kojemu se niti tkanja nisu izvlačile ako bi dio odjeće zapeo za granu ili trn, a isto su tako često upotrebljavali i opanke, koji su bili neophodni za kretanje po uskim kozjim stazama kakve su tada većinom bile na Pelješcu. Muškarci su se snabdijevali i gotovim odijelima (mali vestit, tamni - zimski vestit) s brojnim ovratnicima (koletima) i kravatama. Kravate su se rabile toliko da se može reći da su ih nosili gotovo svakodnevno.

Žene su uvijek imale marame na glavi, ljeti bijele, a inače šarene. Kupovali su i svilene marame i rupčiće, a za posebne je prigode bilo i suncobrana i lepeza (ambrelina i mahonica). Sve to, uključujući i cipele za žene, nabavljali su muški članovi obitelji, koji su imali otvoren račun u prodavaonicama u Trsteniku udaljenom devet kilometara, pa su taj račun povremeno podmirivali. Braenovići su to radili gotovinom, ali se račun mogao platiti i vinom.

Od hobija, muškarci su se vjerojatno bavili lovom jer se u troškovniku nalaze i stavke o kupnji lovačke puške i sačme. Nerijetko se i na putovanju, kao na primjer u Risan u Boki, kupila i poneka kartela lota. Vrlo se često bilježi kupnja veće količine tabaka i lišća, po čemu se dade pretpostaviti da su sva trojica braće pušila.

${ }^{13}$ Za prehranu životinja često su se kupovale simule - pripravak od ostataka pri mljevenju pšenice ili ječma, ili framentunica - kukuruz.

${ }^{14}$ Buhač, bušinak - biljka čiji se prašak pripremao za zaštitu od nametnika (Anić 1998: 92).

${ }^{15}$ Drvena bačvica ovalnoga oblika koja je služila za prijenos galice kojom se polijevala vinova loza.

${ }^{16} 0$ tome svjedoči osamdesetsedmogodišnjak Jozo Bajo Braškin iz Trstenika, koji je kao mladićak imao zadatak upravo umakati grozdove. Taj su posao često obavljali mlađi članovi obitelji, još nedorasli za teže fizičke napore. 


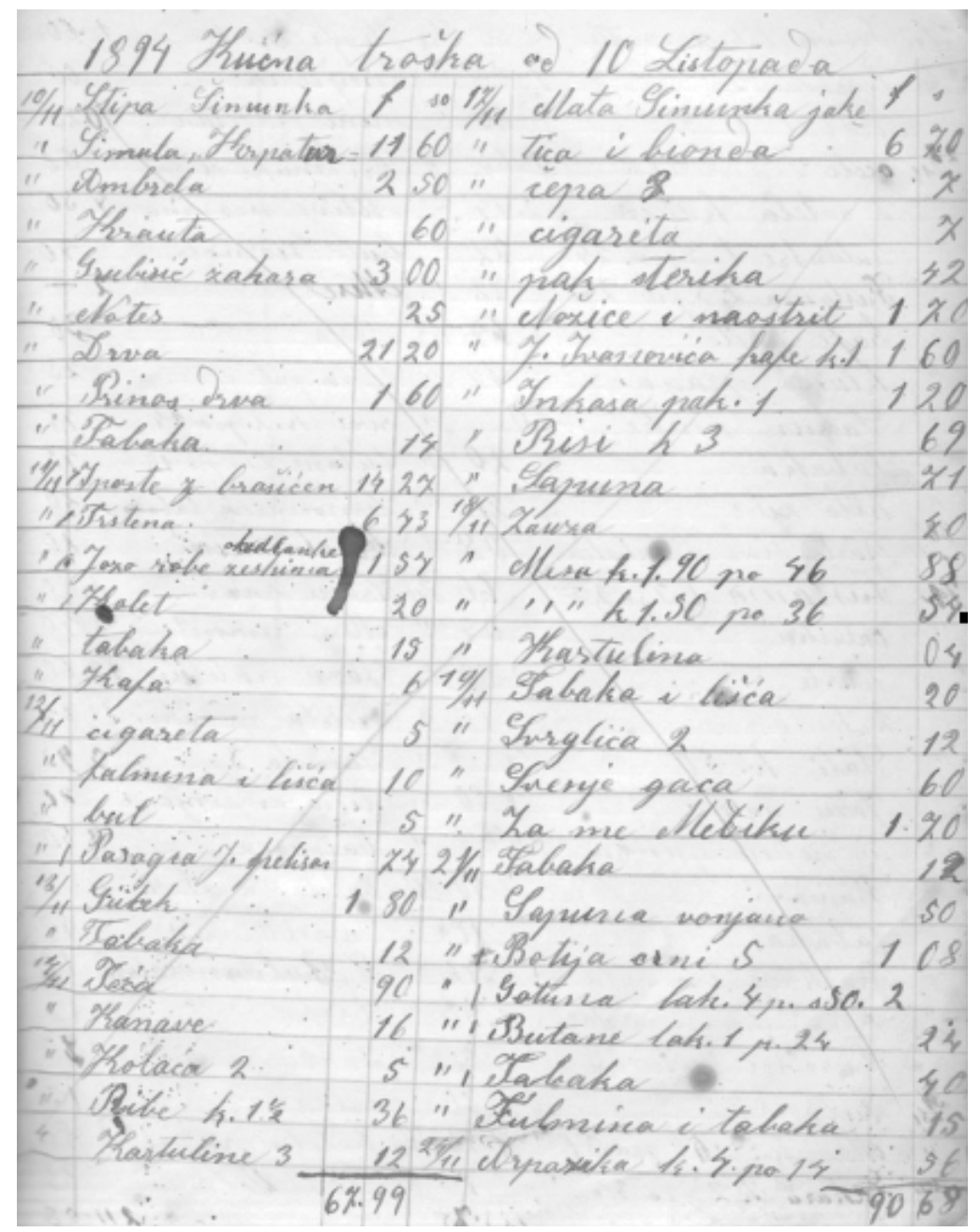

Slika 1. Ogledna stranica kućnog troška za studeni 1894. godine

\section{KRATKI IZVOD IZ KUĆNOG TROŠKA}

Potpuniji uvid u način vođenja bilješki i jezik kojim su se služili predočit će kratka analiza ogledne stranice kućnoga troška. Na početku se spominju Stipo i Mato Šimunko, poznati trgovci koji su imali prodavaonicu mješovite robe u Trsteniku, udaljenom od Grude oko devet kilometara, gdje je sličnu trgovinu držao i Jozo Ivanović. Kod njih su Braenovići često kupovali i imali su otvoren račun. Tako je kupljeno: 
mjehovima gonilo u luke Trpanj, Crkvice ili Trstenik, gdje su pristajali trgovački brodovi.

Tablice 1 i 2 prikazuju vrijeme prodaje i cijene određenih vrsta vina od berbi 1894., 1896. i 1897. godine, te nusproizvoda vina i ulja prodanih tih godina kako bi se dobio uvid u razlike u cijenama. Primjetno je da su najviše cijene svih vrsta vina postignute 1896 . godine, kad je bila najskuplja i rakija, 1894. bilo je dosta pljesnivog vina - blùte, ${ }^{18}$ dok se vinski kamen prodavao tijekom rujna prigodom pripreme bačava za predstojeću berbu. S obzirom na to da je sačuvan detaljni kućni trošak za 1897. godinu i isto tako iscrpan popis prihoda od berbe 1896. godine, zbrajanjem je ustanovljeno da je ukupna zarada obitelji iznosila 3443 forinte i 73 solda. Taj se novac trošio tijekom 1897. godine, za koju postoji potpuni i precizni troškovnik. Tijekom te godine potrošeno je ukupno 1075 forinti i 8 solada, uključujući sve nadnice i kupnju alata za obradu zemlje te sredstva za zaštitu vinograda.

Dakle, obitelji je ostalo 2368 forinti i 65 solada. Riječ je o lijepoj svoti novca pa ne čudi da su kao prilog za otvorenje Hrvatske narodne čitaonice Potomje Braenovići mogli izdvojiti 15 forinti, za Starinsko društvo 6 forinti, a za članarinu u Društvu Ćirila i Metoda 50 solada.

Ukupni prihod od berbe 1894. godine iznosio je 2916 forinti i 93 solda, a od berbe 1897. godine 2886 forinti i 28 solada jer su cijene vina bile nešto niže. Ne računajući nusproizvode i blùta vino, 1894. je prodan 51 hektolitar, 1896. 61, a 1897. godine 53 hektolitra vina. ${ }^{19}$

Navedeni podaci ovdje ne pokazuju posljedice djelovanja "vinske klauzule". ${ }^{20}$ Bez obzira na klimatske uvjete pojedinih godina, ni količine ni cijena proizvedena vina nisu bitnije oscilirale, a u tom je pogledu područje Pelješke župe vjerojatno narednih godina još više profitiralo. Naime, filoksera se ovdje pojavljuje 20-ak godina kasnije nego u Dalmaciji, gdje je proizvodnja naglo padala pa je vino iz ovih južnih predjela bilo traženije i postizalo višu cijenu.

${ }^{18}$ Da je tako bilo i na ostalom dalmatinskom području potvrđuje dopis Trgovačko-obrtničke komore Split od 4. lipnja 1894., u kojemu se od Visoke vlade traži da pomogne seljacima u komorskom okruženju zbog velikih količina pokvarena vina. Moli se dopuštenje da od tog pokvarenog vina mogu praviti rakiju te da za to ne budu podvrgnuti plaćanju pristojbi i carine (Državni arhiv u Dubrovniku, Trgovačko-obrtnička komora 1894. godine, spis br. 244).

${ }^{19}$ Proizvodnja vina u Dalmaciji 1897. bila je znatno niža zbog velike suše koja je rezultirala nerodicom. Tada je Dalmacija imala $770134 \mathrm{hl}$ vina u odnosu na $1126750 \mathrm{hl}$ 1895. i $1354980 \mathrm{hl}$ proizvedena vina 1896. godine. Niži prinosi 1897. zabilježeni su u još nekim zemljama pa je vino bilo traženo na tržištu i prodavalo se po cijeni od 11 do 15 forinti za crno i 12 do 17 forinti za hektolitar bijeloga dalmatinskog vina (Perić 1978: 279). Prema podacima predočenima u tablici uočljivo je da cijene 1897. godine na Pelješcu koreliraju s onima u Dalmaciji, ali nema naznaka nižih prinosa, čak su cijene 1896. bile iznadprosječne i više od onih koje su se postizale 1897. godine.

${ }^{20}$ Riječ je o klauzuli iz trgovačkog ugovora Njemačke i Austro-Ugarske s Italijom iz 1892. godine u kojemu su uz gospodarske važno mjesto imali i politički interesi Njemačke i Austro-Ugarske. Te zemlje su, naime, željele nepouzdanu članicu njihova Trojnog saveza - Italiju čvršće vezati, rješavajući njezine gospodarske teškoće osiguranjem povoljnijeg uvoza talijanskoga vina u Monarhiju. Zbog toga je iz ranijeg ugovora prenesena vinska klauzula koja je značila snižavanje uvoznih carina na talijansko vino. Monarhija je time Dalmaciju, umjesto da joj pomogne, definitivno bacila na koljena (Perić 1978: 264). 


\begin{tabular}{|c|c|c|c|c|c|c|c|c|c|c|c|}
\hline \multicolumn{4}{|c|}{ Intrata* 1894.} & \multicolumn{4}{|c|}{ Intrata 1896.} & \multicolumn{4}{|c|}{ Intrata 1897.} \\
\hline Datum & Vino & $\begin{array}{l}\text { Količina } \\
\text { (hl) }\end{array}$ & $\begin{array}{c}\text { Cijena } \\
\text { za hl }\end{array}$ & Datum & Vino & $\begin{array}{l}\text { Količina } \\
\text { (hl) }\end{array}$ & $\begin{array}{c}\text { Cijena } \\
\text { za hl }\end{array}$ & Datum & Vino & $\begin{array}{l}\text { Količina } \\
\text { (hl) }\end{array}$ & $\begin{array}{c}\text { Cijena } \\
\text { za hl }\end{array}$ \\
\hline 19.01. & Crno & 24 & $8 \mathrm{f}$ & 28.01 . & Crno & 18 & $15 \mathrm{f}$ & 17.02. & Crno & 13 & $11,50 \mathrm{f}$ \\
\hline 15.09. & Trstena* & 1 & $10 \mathrm{f}$ & 22.09. & Trstena & 9 & $16,50 \mathrm{f}$ & 25.06. & Trstena & 8 & $15 \mathrm{f}$ \\
\hline 28.01 & Bijelo & 13 & $14 \mathrm{f}$ & 28.01. & Bijelo & 6 & $16,50 \mathrm{f}$ & 09.03. & Bijelo & 13 & $16,10 \mathrm{f}$ \\
\hline 05.02. & $\mathrm{Opol}^{* * *}$ & 13 & $10 \mathrm{f}$ & 16.06. & Opol & 19 & $15,75 \mathrm{f}$ & 05.02. & Opol & 19 & $12 \mathrm{f}$ \\
\hline- & - & - & - & 01.07. & $\begin{array}{c}\text { Trstena } \\
\text { opol }\end{array}$ & 9 & $18 \mathrm{f}$ & - & - & - & - \\
\hline 16.06. & Bluta $^{* * * *}$ & 13 & $4 \mathrm{f}$ & - & - & - & - & - & - & - & - \\
\hline 28.08 & Bluta & 17 & $4 \mathrm{f}$ & - & - & - & - & - & - & - & - \\
\hline 03.09. & Bluta & 14 & $7 \mathrm{f}$ & - & - & - & - & - & - & - & - \\
\hline
\end{tabular}

Tablica 1. Prihodi od prodaje vina obitelji Braenović

Izvor: Rukopisna ostavština obitelji Braenović (tablicu izradila autorica)

\begin{tabular}{|c|c|c|c|c|c|c|c|c|c|c|c|}
\hline \multicolumn{4}{|c|}{ Intrata 1894.} & \multicolumn{4}{|c|}{ Intrata 1896.} & \multicolumn{4}{|c|}{ Intrata 1897.} \\
\hline Datum & & $\begin{array}{l}\text { Količina } \\
\text { (hl) }\end{array}$ & $\begin{array}{c}\text { Cijena } \\
\text { za hl }\end{array}$ & Datum & & $\begin{array}{l}\text { Količina } \\
\text { (hl) }\end{array}$ & $\begin{array}{c}\text { Cijena } \\
\text { za hl }\end{array}$ & Datum & & $\begin{array}{l}\text { Količina } \\
\text { (hl) }\end{array}$ & $\begin{array}{c}\text { Cijena } \\
\text { za hl }\end{array}$ \\
\hline 22.12 . & Rakija & 0.90 & $28,50 \mathrm{f}$ & 16.06. & Rakija & 6 & $44 \mathrm{f}$ & 26.03 . & Rakija & 5 & $39,50 \mathrm{f}$ \\
\hline 21.12 & Ulje & 1 & $27 \mathrm{f}$ & - & - & - & - & - & - & - & - \\
\hline 15.05 . & Ocat & 3 & $7 \mathrm{f}$ & - & - & - & - & - & - & - & - \\
\hline 23.09. & Striš i feca $a^{* * * * *}$ & - & $31 \mathrm{f}$ & - & - & - & - & 01.09 . & Feca & - & $11 \mathrm{f}$ \\
\hline
\end{tabular}

Tablica 2. Prihodi od prodaje nusproizvoda vina i ulja obitelji Braenović Izvor: Rukopisna ostavština obitelji Braenović (tablicu izradila autorica)

* Od tal. entrata, što znači ulaz, dakle prihod, ono što se dobilo od berbe.

** Trstena - vino od grožđa iz vinograda sa područja Trstenika, odgovara današnjem Postupu i tada je kao i danas bilo skuplje od ostaloga crnog vina- prosječno za dvije forinte (pojasnila J. M.).

*** “Opoli su vina žive, crvene boje, puna, dovoljo jaka, a malo kisela” (Bobanović i Ivon-Bilić 1927: 101).

**** "Blùta (mufa, zavrelica) bolest koja se pojavljuje navlastito na vinima koja oskudijevaju vinskom kiselinom i u kojima je ostalo neprevrela sladora. Koristilo se za destilaciju, odnosno za pravljenje rakije" (Bobanović i Ivon-Bilić 1927: 101).

***** Striš ili striješ je osušeni ili suhi talog koji se skupljao na bočnim stranama bačve i sa njih strugao. Poznat je i naziv vinski kamen. Strišari su dolazili na Pelješac naročito iz Makarskog primorja. Feca je talog vina koji se vadio kroz purtelu, otvor u dnu bačve (kazivanje Joza Baja Braškina). 
Analizom visine prihoda i strukture rashoda obitelji Braenović, koja je potkraj 19. stoljeća funkcionirala kao složeno kućanstvo, te usporedbom s visinom nadnica običnog težaka (polovnika) i njegovom kupovnom moći s obzirom na tadašnje cijene, dobiva se jasna slika financijskoga stanja obitelji.

Visina prihoda od "trećina" i "polovina" sa zemlje u zakupu, kao i prihoda od prodaje vina, nusproizvoda vina i ulja nedvojbeno pokazuje kako je riječ o dobrostojećoj zemljoposjedničkoj obitelji čiji su si članovi mogli dopustiti svakodnevne izdatke koji su u tadašnjim gospodarskim prilikama doista bili luksuz.

Upravo u ekonomskoj snazi obiteljske kućne zadruge leži objašnjenje kako je obitelj prebrodila gospodarske potrese izazvane "vinskom klauzulom" iz ugovora Austrije i Italije iz 1892. godine, krizu brodarstva te odolijevala peronospori i nerodicama, tim više što je odmah nakon uvođenja "klauzule" uslijedio pad cijena dalmatinskoga vina. Godine 1891. prosječna cijena jednog hektolitra vina iznosila je 15,91 forintu, 1892. 11,46 i 1893. godine 9,57 forinti s tendencijom daljnjeg pada (Kraljević 1994: 207). Na Pelješcu nema podataka za te godine, ali je naredne, 1894 . godine, prosječna prodajna cijena bila 10,5, 1896. 15,9 a 1897. godine 13,65 forinti za jedan hektolitar vina (tablica 1) ${ }^{21}$ Cijene, dakle, nisu progresivno opadale, a najviše su 1896. godine. Bez obzira na to što su baš 1897. vladale suša i nerodica i kod nas i u susjednim zemljama, urod je podbacio pa je vino bolje prolazilo i bilo traženije. Tada se crno vino prodavalo po cijeni od 11-15 a bijelo od 12-17 forinti (Perić 1978: 279). U izvoru obitelji Braenović može se iščitati da je te godine cijena crnoga vina bila 11,50 a bijeloga 16,10 forinti, što odgovara predočenu dalmatinskom prosjeku, ali su 1896. pelješki vinogradari postigli znatno više cijene od prosječnih u Dalmaciji. ${ }^{22}$

Na temelju proučenoga troška zamjetno je da je, barem s financijske strane, život Braenovića bio bitno lagodniji od života većine peljeških obitelji toga vremena. Na Pelješkoj župi su tada bile česte emigracije u prekomorske zemlje, ali iz obitelji Braenović nitko nije iselio. Oni su bili gospari - njihovo vino se uvijek prvo prodavalo, a čak je troje djece braće Braenovića školovano, pa je u obitelji bio kapetan, svećenik i činovnik. Iz podataka znamo da je ta kućna zadruga npr. 1897. godine imala čisti dohodak od 2368 forinti, što im omogućuje ulaganje u obveznice i dionice (o čemu svjedoče dodatni

${ }^{21}$ U Dalmaciji su 1894. godine prosječne cijene bile 8-12 forinti za hl, 1895. 10-15, 1896. 9-13, a 1897. godine 10-12 forinti po hl (Bulić 1922: 99-100). Kao autor niza članaka u časopisu Zadrugar pod nazivom "Iz prošlosti naše vinske trgovine" Stjepan Bulić je cijene vina prikazao u krunama, a ovdje su radi lakše usporedbe preračunate u forinte. I u usporedbi s tim izvorom cijene vina su na Pelješcu 1896. i 1897. godine premašivale gornje prosječne vrijednosti cijena u Dalmaciji tih godina.

${ }^{22}$ Crno vino odgovaralo bi današnjem plavcu, to je, dakle, obično crno vino, a ono koje je označeno kao trstena (od Trstenik) također je crno, ali kvalitetno primorsko vino, današnji postup ili dingač, čija je cijena uvijek bila na razini bijelih vina ili viša. Uz bijelo vino prodavao se i opol, koji je također postizao višu cijenu (pojasnila J. M.). 
dokumenti iz kućne ostavštine). Budući da su bili pismeni, pretplaćeni na više tiskovina i upućeni u moderne trendove ulaganja kapitala može ih se smatrati seoskim aristokratskim slojem, svojevrsnom intelektualnom kremom pelješke ruralne sredine. ${ }^{23}$

\section{EVIDENTIRANI PRIHODI OD PELJEŠKIH VINOGRADA TIJEKOM KONJUNKTURE}

Cijene i količine prodana vina na Pelješcu ne naslućuju vinogradarsku krizu izazvanu "klauzulom" i potvrđuju da je područje bivše Dubrovačke Republike imalo posve drukčiju putanju razvoja te gospodarske grane od ostatka Dalmacije. Potkraj 19. stoljeća pelješko se vino bolje prodavalo i bilo je traženije pa su i emigracijska kretanja više uvjetovali tranzicijska prenapučenost, propast brodarstva i u pojedinim područjima dioba zemlje nego nemogućnost prodaje vina ili filoksera kao u tada vinogradarski najnaprednijim dijelovima srednje i sjeverne Dalmacije. Rukopisna ostavština obitelji Braenović sadrži i evidenciju o cijenama i prodanu vinu i rakiji tijekom središnjeg dijela "velike vinske konjunkture" 1873-1883. godine. Prikazane cijene i količina vina prodana veletrgovcima koji su otkupljivali vino od većeg broja proizvođača na središnjem dijelu poluotoka potvrđuju da na ovom području nije bilo enormnog povećanja cijena i izvoza vina, kao što to prikazuju izvori koji se odnose na područje Splitske trgovačke komore ili dalmatinska statistička izvješća. ${ }^{24}$

\footnotetext{
${ }^{23} \mathrm{O}$ doista aristokratskom stavu svjedoče i danas njihovi portreti koje je izradio čuveni Mato Celestin Medović. Dominiraju zidovima obiteljske kuće i još uvijek nas promatraju ozbiljna i stroga izraza lica na kojima se ističu pomno uređeni brkovi i brada.

${ }^{24}$ U kulminacijskoj fazi "velike konjunkture" cijene od 25 do 30 forinti za hektolitar, koje donose neki dalmatinski izvori, mogle su se odnositi samo na glavni izvozni pravac prema Francuskoj, dok su se unutar pokrajine i na tršćanskome tržištu kretale od minimalnih 12-15, preko srednjih 16-18, do maksimalnih 30-32 forinte za hektolitar (Kraljević 1994: 100).
} 


\begin{tabular}{|c|c|c|c|c|c|}
\hline Godina & Datum & Vino & Rakija & $\begin{array}{c}\text { Količina } \\
\text { bareli }\end{array}$ & $\begin{array}{c}\text { Cijena - } \\
\text { forinti za barel }\end{array}$ \\
\hline 1873. & $\begin{array}{l}\text { 21. ožujka } \\
\text { 27. ožujka } \\
\text { 22. kolovoza }\end{array}$ & & 29. srpnja & $\begin{array}{c}16,5 \\
17,3 \\
2 \\
18\end{array}$ & $\begin{array}{c}9 \\
9 \\
23 \\
15\end{array}$ \\
\hline 1875. & 12. travnja & opol & 12. travnja & $\begin{array}{l}1,5 \\
1,5\end{array}$ & $\begin{array}{c}7,5 \\
26,5\end{array}$ \\
\hline 1877. & $\begin{array}{l}\text { cijela godina } \\
\text { bez datuma }\end{array}$ & & & $\begin{array}{c}10 \\
25 \\
6 \\
9 \\
2 \\
4\end{array}$ & $\begin{array}{c}7 \\
6,40 \\
6,25 \\
5,20 \\
5,50 \\
5,50\end{array}$ \\
\hline 1878. & $\begin{array}{l}\text { 11. siječnja } \\
\text { 11. siječnja } \\
\text { 11. siječnja } \\
\text { 11. siječnja } \\
\text { 17. veljače } \\
\text { 15. travnja } \\
\text { 10. kolovoza } \\
\text { 18. rujna }\end{array}$ & & $\begin{array}{l}\text { 17. veljače } \\
\text { 15. travnja }\end{array}$ & $\begin{array}{c}28 \\
16,3 \\
20,9 \\
16 \\
/ \\
17 \\
5 \\
4 \\
5 \\
22 \\
/ \\
8,9 \\
18,1\end{array}$ & $\begin{array}{c}9,30 \\
7,50 \\
5 \\
3,50 \\
25 \\
4,80 \\
5,50 \\
4 \\
5,50 \\
8,1 \\
25 \\
16 \\
5\end{array}$ \\
\hline 1879. & $\begin{array}{l}\text { 12. siječnja } \\
\text { 9. ožujka } \\
\text { 22. ožujka } \\
\text { 29. ožujka } \\
\text { 27. travnja } \\
\text { 30. lipnja }\end{array}$ & bijelo & prosinac & $\begin{array}{c}12 \\
11,9 \\
32 \\
10 \\
16 \\
26 \\
/\end{array}$ & $\begin{array}{c}5,75 \\
7 \\
5 \\
6,50 \\
4,25 \\
3,50 \\
18\end{array}$ \\
\hline 1880. & $\begin{array}{l}\text { 16. ožujka } \\
\\
\text { 5. srpnja } \\
\text { 5. kolovoza } \\
\text { 26. kolovoza } \\
\text { 27. rujna }\end{array}$ & & 16. ožujka & $\begin{array}{l}16 \\
7 \\
/ \\
12 \\
17 \\
12 \\
2\end{array}$ & $\begin{array}{c}5,40 \\
5 \\
19 \\
7,20 \\
5,50 \\
3,50 \\
15\end{array}$ \\
\hline 1881. & $\begin{array}{l}\text { 13. siječnja } \\
\text { 13. siječnja } \\
\text { 18. ožujka } \\
\text { 18. ožujka } \\
\text { 1. lipnja } \\
\text { 15. lipnja } \\
\text { 16. rujna }\end{array}$ & $\begin{array}{c}\text { opol - crno } \\
\text { opol - bijelo } \\
\text { crkveno } \\
\text { bijelo }\end{array}$ & & $\begin{array}{c}13,5 \\
2 \\
2,9 \\
22 \\
8 \\
13 \\
13 \\
22,5\end{array}$ & $\begin{array}{c}8 \\
8 \\
8,25 \\
8 \\
9 \\
8,75 \\
6,50 \\
11,50\end{array}$ \\
\hline 1882. & $\begin{array}{l}\text { 13. veljače } \\
\text { 27. veljače } \\
\text { 24. ožujka } \\
\text { 24. kolovoza } \\
\text { 7. studenoga }\end{array}$ & & & $\begin{array}{c}11,5 \\
29,9 \\
2,5 \\
16 \\
21\end{array}$ & $\begin{array}{c}8,50 \\
9 \\
10,50 \\
8 \\
5,25\end{array}$ \\
\hline 1883. & nema cijena & prodaja minim. & & & \\
\hline
\end{tabular}

Tablica 3. Trgovanje vinom i rakijom na Pelješcu tijekom kulminirajućeg dijela velike konjunkture. Izvor: Rukopisna ostavština obitelji Braenović (tablicu izradila autorica) 
Iako se ne zna je li nepostojanje bilježaka za pojedine godine stvar nedostatne evidencije, nerodne godine ili loše prodaje, ipak se može dobiti okvirna slika o cijenama vina navedenih godina. Svega nekoliko nepotpunih bilješki o prodaji 1874. godine, kad je naznačena pojedinačna prodaja sacchi di vino, upućuju na zaključak o lošoj godini i malim količinama vina. Vrsta vina također nije dosljedno bilježena, nedostaje poneki nadnevak, ali se može zaključiti: cijene su 1881. i 1882. godine više nego prijašnjih godina, bijelo vino imalo je nešto višu cijenu, kao i ono prodano u kolovozu u odnosu na zimske mjesece. Njegova vrlo niska cijena u rujnu 1878. i kolovozu 1880. navode na upitnu kvalitetu ili poteškoće u plasmanu vina. Rast cijena počinje od rujna 1880. godine i održava se na razini 8 do 11,5 forinti za barel ili 9,60 do 17 forinti za hektolitar, ${ }^{25}$ što je u okvirima minimalnih vrijednosti na razini pokrajine Dalmacije, a sve su cijene iznos koji je seljak dobivao za svoje vino od nakupaca i trgovaca. Navedeno potvrđuje da na Pelješcu nije bilo naglih skokova cijena ni povećane potražnje vina ni u jesen 1882. godine, kad su u Dalmaciju došli brodovi s kupcima iz Francuske i Njemačke.

Imajući u vidu činjenicu da nakon 1892. godine počinje kriza vinogradarstva i dalmatinskoga gospodarstva uopće te da na tržištu ponestaje vina, iskazane više cijene i potražnja vina na južnodalmatinskome području su očekivane (Maslek 2012: 191, 192). Monokulturni uzgoj vinove loze i sporo širenje filoksere upućuju zato na naizgled paradoksalan zaključak da je Pelješac posljednjih godina 19. stoljeća svojevrsna konjunkturna oaza, što prikazani podaci iz rukopisne ostavštine pelješke obitelji Braenović i potvrđuju.

Analizom toga povijesnog izvora pokušalo se predočiti kako, tragajući za gospodarskim i društvenim strukturama duga trajanja i promišljajući različite socijalne manifestacije lokalne povijesti, tzv. "nova povijest" razotkriva brojne nove teme i nudi nove interese drukčijim pristupom istraživanju izvorne građe. Kućni trošak obitelji Braenović trebao je poslužiti za upravo takvo, novo i drukčije promišljanje života i rada jedne obitelji u kratkom povijesnom isječku i u konkretnim društveno-gospodarskim okolnostima.

Tradicionalne vrijednosti izražene seoskom svakodnevicom i prevladavajuća gospodarska aktivnost na poluotoku krajem 19. stoljeća iščitani iz izvora obitelji Braenović postale su dijelom kulturnoga prostora u pulsirajućoj isprepletenosti sa širim prostorom Sredozemlja. Trgovanje vinom i drugim poljoprivrednim proizvodima uvjetovalo je stalne doticaje i višestruke veze s ostalim državama i pokrajinama. Te su se veze održavale morem kao osnovnom poveznicom ovoga stiješnjenoga i izoliranoga poluotočnoga prostora $\mathrm{s}$ dijelom sredozemnoga kulturnog areala, u kojemu se prepoznaje gotovo identična struktura obitelji, način nasljeđivanja i imovinsko zajedništvo,

${ }^{25} \mathrm{U}$ izračunu je iskorištena zapremina splitskoga barela koji iznosi 67,68 litara (prema Tartaglia 1901: 38). 
posebice u seoskim tradicionalnim sredinama u Francuskoj, Španjolskoj i Italiji. Primjer zajedništva oženjene braće u Francuskoj i njihovoga zajedničkoga gospodarenja na nepodijeljenoj zemlji vrlo je blizak idealu utisnutu u kolektivni mentalitet tradicionalnoga dubrovačkoga okružja - spriječiti usitnjavanje posjeda i financijskim i imovinskim zajedništvom pridonositi dobrobiti i snazi svake obiteljske zajednice. Zato se s pravom može zaključiti da i ekonomska snaga te proširene obitelji počiva upravo na zajedništvu kojim su pronađeni načini i mogućnosti prilagodbe lokalnoga gospodarenja zahtjevima novih, modernih modela robno-novčanih odnosa. ${ }^{26}$

\section{NAVEDENA LITERATURA I IZVORI}

Anić, Vladimir. 1998. Rječnik hrvatskoga jezika. Zagreb: Novi Liber.

Bertoša, Miroslav. 2002. “Demografija predindustrijske Europe. Od statističke analize do 'zlokobnih tajni'”. U Miroslav Bertoša. Izazovi povijesnog zanata. Lokalna povijest i sveopći modeli. Zagreb: Antibarbarus, 313-349.

Bobanović, Mato i Oskar Ivon-Bilić. 1927. Radnje oko vina. Split: Splitska društvena tiskara E. Desman.

Braudel, Fernand. 2001. Mediteran i mediteranski svijet u doba Filipa II., 1. Podgorica, Beograd: CID, Geopoetika.

Bulić, Stjepan. 1922. "Iz prošlosti naše vinske trgovine”. Zadrugar 13.

Čapo, Jasna. 1991. "Jedno povijesno-etnološko tumačenje kućanstava, na primjeru vlastelinstva Cernik od 1760. do 1850. godine". Narodna umjetnost 28: 329-348.

Čapo Žmegač, Jasna. 1996. "Konstrukcija modela obitelji u Europi i povijest obitelji u hrvatskoj”. Narodna umjetnost 33/2: 179-196.

Čapo Žmegač, Jasna. 1998. "Seoska društvenost”. U Etnografija, svagdan i blagdan hrvatskoga puka. Zagreb: Matica hrvatska, 251- 295.

Černelić, Milana. 2009. “Običajno-pravni i imovinski aspekti života u obiteljskim zadrugama Like”. Senjski zbornik 36: 301-322. Dostupno na: http://hrcak.srce.hr/57617.

Ćosić, Stjepan. 1999. Dubrovnik nakon pada Republike (1808-1848.). Dubrovnik: Zavod za povijesne znanosti HAZU.

Glavina, Frano. 2010. Dubrovački gospari i pelješki kmetovi. Dubrovnik: Državni arhiv u Dubrovniku.

Gross, Mirjana. 1996. "Susret historije i antropologije". Narodna umjetnost 33/2: 71-86.

Kraljević, Rudolf. 1994. Vinogradarski slom i demografski rasap Južne Hrvatske u osvit 20. stoljeća. Split: Književni krug.

Maslek, Jasenka. 2012. Vinogradarstvo na poluotoku Pelješcu (1815-2000.) i njegov utjecaj na razvoj stanovništva. [Doktorska disertacija].

${ }^{26}$ Zadržavanjem proširene obiteljske strukture Braenovići kasnije lakše odolijevaju vanjskim otegotnim okolnostima pa se zajednica raskida tek višom silom, smrću najstarijeg od trojice braće. 
Pavličević, Dragutin. 1989. Hrvatske kućne zadruge, 1. Zagreb: Liber, Zavod za hrvatsku povijest Filozofskog fakulteta u Zagrebu.

Pavličević, Dragutin. 2010. Hrvatske kućne/obiteljske zadruge, 2. (nakon1881.). Zagreb: Golden marketing-Tehnička knjiga.

Perić, Ivo. 1978. "'Vinska klauzula' u pretposljednjem trgovinskom ugovoru između AustroUgarske i Italije i njene posljedice u Dalmaciji". Rad JAZU 375: 257-296.

Sarti, Raffaella. 2006. Živjeti u kući. Stanovanje, prehrana i odijevanje u novovjekovnoj Europi (1500-1800.). Zagreb: Ibis grafika.

Sicard, Emile. 1974. "Razmišljanja o postojanju i konceptu kućnih ekonomskih zajednica”. Sociologija sela 12/1: 28-52.

Stipetić, Vladimir. 1959. Kretanje i tendencije u razvitku poljoprivredne proizvodnje na području NR Hrvatske. Zagreb: JAZU.

Šundrica, Zdravko. 1980. “Stonski rât u XIV stoljeću (1333 - 1399.)”. Pelješki zbornik 2: 73190.

Tartaglia, Miho. 1901. Vinarski i vinogradarski Almanak za godinu 1901. Split: Vinarska udružba za Dalmaciju.

Vekarić, Nenad. 1989. Pelješka naselja u 14. stoljeću. Dubrovnik: Zavod za povijesne znanosti JAZU u Dubrovniku.

Vekarić, Nenad. 1992a. “Demografski uzroci iseljavanja s dubrovačkog područja u Ameriku u 19. i početkom 20. stoljeća". Dubrovnik 3/5: 97-102.

Vekarić, Nenad. 1992b. Stanovništvo poluotoka Pelješca, 1. Dubrovnik: Zavod za povijesne znanosti HAZU u Dubrovniku.

Vekarić, Nenad. 1995. Pelješki rodovi (A-K). Dubrovnik: Zavod za povijesne znanosti HAZU u Dubrovniku.

Vekarić, Nenad i Božena Vranješ-Šoljan. 2009. Početak demografske tranzicije u Hrvatskoj. Zagreb, Dubrovnik: HAZU, Zavod za povijesne znanosti u Dubrovniku, [uvodna studija] 9-62.

Vekarić, Stjepan i Nenad Vekarić. 1987. “Tri stoljeća pelješkog brodarstva (1600-1900)”. Pelješki zbornik 4.

Wertheimer-Baletić, Alica. 1999. Stanovništvo i razvoj. Zagreb: Mate.

\section{Dodatni izvori}

Matične knjige rođenih, vjenčanih i umrlih župe Kuna Pelješka

Državni arhiv u Dubrovniku, Trgovačko-obrtnička komora 1894. godine

Državni arhiv u Dubrovniku, Testamenta Notariae, ser. 10, sv. 85, f. 162-164

Kazivanje Joza Baja Braškina 


\title{
HOUSEHOLD EXPENDITURE OF THE BRAENOVIĆ FAMILY FROM PELJEŠAC IN THE LATE 19TH CENTURY: A SOURCE FOR INTERPRETING THEIR DAILY LIFE
}

\begin{abstract}
SUMMARY
The paper analyses the income and expenditure inventories of the Braenović family, landowners from Gruda near Potomje on the Pelješac Peninsula at the close of the nineteenth century, based on their family records which served as the main source for this research. After an introductory survey of the broader social conditions in which the family lived and worked, the paper focuses on the family's everyday life from 1894 to 1897, documented in detail by the expenditure records and the inventories of the purchased items by price. The available data provides an insight into the customs, clothing and family everyday life, but also into labourers' daily wages and their value with regard to the prices cited in the household expenditure. The records of the family wine trade and the income from the wine harvest and wine sales give a clear view of their financial status. On the basis of a detailed list of all expenditures over a period of several years in succession, a parallel is drawn between the income in 1896 and the expenditure in the following year, 1897. The results unquestionably show that the family under study were well-established landowners whose daily expenditures by far exceeded the current economic conditions and fell under luxury. Family records of the sale and prices of wine during the great wine conjuncture are a most valuable source for drawing comparison with the regional wine trade and a proof of varied development conditions of this economic activity and its reflection on the demographic sphere.
\end{abstract}

Key words: landownership, family everyday life, household expenditure, financial effect of the grape harvest, wine conjuncture 